DOI: 10.17707/AgricultForest.64.2.01

Gordan S. KARAMAN ${ }^{1}$

\title{
FURTHER DISCOVERY OF NEW OR PARTIALLY KNOWN TAXA OF THE GENUS NIPHARGUS SCHIÖDTE, 1849 (FAM. NIPHARGIDAE) IN GREECE (CONTRIBUTION TO THE KNOWLEDGE OF THE AMPHIPODA 302)
}

\section{SUMMARY}

The new subterranean subspecies of the genus Niphargus Schiödte, 1849 (Amphipoda Gammaridea, Niphargidae), N. (Orniphargus) lourensis skirosi, ssp. $\mathrm{n}$. is described and figured from the underground waters of Skiros Island in the Aegean Sea (Greece), taxon rather similar to the nominal species N.(Orniphargus) lourensis Fišer et al. 2006 described and known based on one single specimen from Epirus region of Greece only.

Niphargus (Orniphargus) lindbergi S. Karaman 1956, described and known based on single specimen from Attica region of Greece only (Draconera Cave), is established in Thessaly region also [spring on main road Lamia-Larissa (=Laritza) in Central Greece], and new taxonomical data of this species from both localities are presented. The presented data put some more lights on the taxonomical position of these taxa. The mentioned taxa, Niphargus lourensis, skirosi and lindbergi belong to the subgenus Orniphargus S. Kar. 1950.

Keywords: Subterranean waters, taxonomy, Amphipoda, Niphargus, Orniphargus, lourensis, skirosi, lindbergi, Greece.

\section{INTRODUCTION}

The freshwater fauna of Amphipoda in Greece has been intensively studied by various scientists, and numerous new species of this group have been discovered and described. The investigations of the subterranean waters in Greece with prevalently calcareous rocks and karstic phenomena, showed the high richness of subterranean endemic genera and species, especially within the family Niphargidae.

Because of hard sampling and often scarce number of collected specimens, some new species were described based on single male or female specimen (Niphargus lindbergi S. Karaman 1956; N. lourensis Fišer et al. 2006, N. cimbalus G. Karaman 2017, N. rhodi S. Karaman 1950c, etc.]. The recent discovery of numerous new taxa request much more detailed description of taxonomical characters of each species, and new redescription of these taxa based on the same or other localities is necessary to understand the taxonomical position of these species and its relations to other Niphargus taxa.

\footnotetext{
${ }^{1}$ Gordan S. Karaman (corresponding author: karaman@t-com.me), Montenegrin Academy of Sciences and Arts, Podgorica, Montenegro

Note: The author declare that he has no conflicts of interest. Authorship Form signed online.
} 
Discovery of $N$. lindbergi in one new locality (Thessaly), urged us to partially redescribe this species known from Draconera Cave (Attica) only. Thanks to Prof Dr Giuseppe Pesce from the University of Aquilla, who sent us collected samples of Amphipoda from Greece accompanied by some physical and chemical parameters (Pesce \& Maggi 1983), we have possibility to study the samples of Niphargus from Skiros Island in Greece.

The specimens from Skiros Island are rather similar to $N$. lourensis, but based on present known taxonomical characters of $N$. lourensis, not identic with later, considering the specimens from Skiros as a distinct new subspecies, $N$. lourensis skirosi, ssp. n.

\section{MATERIAL AND METHODS}

The studied material of amphipods has been collected by hand-net in the wells and springs and preserved in the $70 \%$ ethanol. The specimens were dissected using a WILD M20 microscope and drawn using camera lucida attachment. All appendages were temporarily submersed in the mixture of glycerin and water for study and drawing. The body-length of examined specimens was measured from tip of head to end of telson using camera lucida. All illustrations were inked manually. After the end of the study, the dissected body-parts were submerged in Liquid of Faure and covered by cover glass for final preservation. Some body-parts of holotype were drawn directly from holotype-slides.

Some morphological terminology and seta formulae follows Karaman`s terminology (G. Karaman, 1969) for the last mandibular palpus [A= A-setae on outer face; $\mathrm{B}=\mathrm{B}$-setae on inner face; $\mathrm{C}=$ additional setae on outer face; $\mathrm{D}=$ lateral marginal $\mathrm{D}$-setae; $\mathrm{E}=$ distal long E-setae] and for propodus of gnathopods 1 and 2 (G. Karaman, 2012) [S = corner S-spine; L = lateral slender serrate Lspines; $\mathrm{M}$ = facial $\mathrm{M}$-setae; $\mathrm{R}$ = subcorner R-spine on inner face]. Terms "setae" and "spines" are used based on shape, not origin.

All investigations are based on provided morphological, ecological and zoogeographical investigations and data.

\section{TAXONOMICAL PART}

\section{Family NIPHARGIDAE}

\section{NIPHARGUS (ORNIPHARGUS) LOURENSIS SKIROSI ssp. n.}

Figures 1-6

Niphargus sp. Pesce \& Maggi 1983: 34.

MATERIAL EXAMINED: GREECE:

G-212= Skiros island, Molos, $50 \mathrm{~m}$ from the coast, 2 wells, water temperature $15.2^{\circ} \mathrm{C}$, pH 7.3, 1.7.1980, 2 exp. (leg. G. Pesce); 
G-213.= Skiros island, Molos, radar station, 2 wells, water temperature $13.3^{\circ} \mathrm{C}, \mathrm{pH} 7.1,1.7 .1980,2$ exp. (leg. G. Pesce) (locus typicus);

G-216= Skiros island, Road Linaria-Skiros, $6 \mathrm{~km}$ from Skiros city, 2 wells, pH 7.1, water temperature $15.0^{\circ} \mathrm{C}, 2.7 .1980,3$ exp. (leg. G. Pesce);

G-217= Skiros island, Aspous, 2 wells, along the road Linaria-Skiros, water temperature $15.1^{\circ} \mathrm{C}$, pH 7.1, 2.7.1980, 1 exp. (leg. G. Pesce);

G-218= Skiros island, Aspous, 2 wells, along the road Linaria-Skiros, water temperature $15.1^{\circ} \mathrm{C}$, pH7.1, 2.7.1980, 1 exp. (leg. G. Pesce);

G-222= Skiros Island, along road Linaria-Skiros, 2 km. from Linaria, water temperature $15.1^{\circ} \mathrm{C}, \mathrm{pH} 7.1$, 3.7.1980, 4 exp. (leg. G. Pesce).

\section{DIAGNOSIS:}

The subspecies skirosi is rather similar to Niphargus lourensis lourensis, but maxilla 1 inner plate is with 2-3 setae, outer plate with 6 spines bearing 1 lateral tooth, only mesial spine with 3-5 teeth, palpus is hardly longer, with 5-7 setae; urosomal segment 1 on each dorsolateral side with one seta; urosomal segment 2 on each dorsolateral side with one strong spine. Coxa 4 is unlobed. Gnathopods 1-2 with trapezoid propodus having rather inclined palm and dactylus with a row of setae along outer margin. Propodus of gnathopod 2 with L-spines sitting partially behind corner S-spine or sitting laterally of S-spine.

Dactylus of pereopods 3-7 at inner margin with one spine near basis of the nail; article 2 of pereopods 5-7 without distinct ventroposterior lobe. Epimeral plates are distinctly angular. Pleopods 1-3 with 2 retinacula, peduncles scarcely setose. Uropod 1 with equal rami. Uropod 3 moderately slender, with short distal article of outer ramus. Lobes of telson are mainly with 4 short distal spines; lateral and facial spines are absent.

\section{DESCRIPTION: Male 8.0 (from G-213):}

Body moderately slender, head with short rostrum and short subrounded lateral cephalic lobes (fig. 3E), eyes absent. Metasomal segments 1-3 with 3-4 dorsoposterior marginal setae (fig. $1 \mathrm{H}$ ). Urosomal segment 1 on each dorsolateral side with one slender seta; urosomal segment 2 on each dorsolateral side with one strong spine; urosomal segment 3 naked. Urosomal segment 1 at each ventroposterior corner with one spine near basis of uropod 1 peduncle (fig. 3G).

Epimeral plates are distinctly angular. Epimeral plate 1 is provided with slightly concave ventral margin and convex posterior margin bearing 3-4 setae, ventroposterior corner is with stronger seta (fig. 1H). Epimeral plate 2 is with slightly convex ventral margin bearing 3 subventral spines, posterior slightly convex margin bearing 4-5 short setae, ventroposterior corner is marked by spine-like seta (fig. 1H). Epimeral plate 3 is with poorly convex ventral margin bearing 4 subventral spines, ventroposterior corner is well marked by spine-like seta, posterior margin is poorly convex bearing 3-4 short setae (fig. 1H).

Antenna 1 reaching nearly half of body-length; peduncular articles 1-3 progressively shorter (ratio: 48:40:27), scarcely setose (fig. 1A); main flagellum 
is scarcely setose, consisting of 14 articles (most of them with one aesthetasc) (fig. 1B). Accessory flagellum is 2-articulated (fig. 1A), not reaching half of peduncular article 3 .

Antenna 2 is moderately slender; peduncular article 3 with one ventral bunch of longer setae; peduncular article 4 is hardly longer than article 5 (ratio: 75:71), at ventral margin with 2 bunches of setae (the longest setae are remarkably longer than diameter of article itself, along dorsal margin with several bunches of short setae; article 5 at ventral margin with 4 bunches of setae (the longest setae slightly exceeding diameter of article itself), along dorsal margin with several bunches of short setae. Flagellum is slightly longer than last peduncular article and consisting of 8 moderately slender articles (fig. 1C); antennal gland cone short (fig. 1C).

Mouthparts: Labrum is broader than long, with almost poorly concave distal margin (fig. 1D). Labium is much broader than long, with small well developed inner lobes and entire broad outer lobes (fig. 2A).

Mandible is with triturative molar. Right mandible: incisor with 4 teeth, lacinia mobilis bifurcate, with several teeth, accompanied by 6 rakers (fig. 5A). Left mandible: incisor with 5 teeth, lacinia mobilis with 4 teeth accompanied by 6 rakers. Palpus 3-articulated: first article is naked, second article is provided with 11-12 strong setae; article 3 is falciform, longer than article 2 (ratio: 75:66), provided with nearly $20 \mathrm{D}$-setae and 5 long distal E-setae, on outer face appear a row of 6 A-setae and one single additional A-seta (fig. 5B), on inner face are attached 4 long single B-setae (fig. 5C).

Maxilla 1: inner plate is with 3 distal setae, outer plate is provided with 7 spines [6 spines are with one lateral tooth, one (mesial) spine is provided with 34 lateral teeth] (fig. 1F), palpus is 2-articulated, second article hardly exceeding basis of outer plate-spines and provided with 5 distal setae (fig. 1E).

Maxilla 2: both lobes are almost equal, longer than broad and provided with numerous distal marginal setae only (fig. 3F).

Maxilliped: inner plate is short, with 3 distal pointed spines mixed with several longer setae (fig. $1 \mathrm{G}$ ); outer plate reaching nearly half of palpus article 2 and provided with nearly 12 short spines and several proximal and distal setae; palpus article 3 along outer margin with 1-2 median setae, palpus article 4 at inner margin with one seta near basis of the nail (fig. 1G).

Coxae 1-4 are relatively short. Coxa 1 is slightly broader than long (ratio: 40:36), with subrounded ventral margin provided with nearly 5 setae (fig. 2B). Coxa 2 is longer than broad (ratio: 55:47), along ventral subrounded margin with 10 setae (fig. 2E). Coxa 3 is longer than broad (ratio: 57:49), with 9 marginal setae (fig. 3A); coxa 4 is slightly longer than broad (ratio: 57:52), with 8 setae along ventral margin, ventroposterior lobe absent, posterior margin is slightly concave (fig. 3C). Coxa 5 is poorly shorter than coxa 4, bilobed, much broader than long (ratio: 60:40) (fig. 4A). Coxa 6 is smaller than coxa 5, bilobed, broader than long (ratio: 50:32) (fig. 4C). Coxa 7 is much broader than long (ratio: 48:20), entire (fig. 4E). 


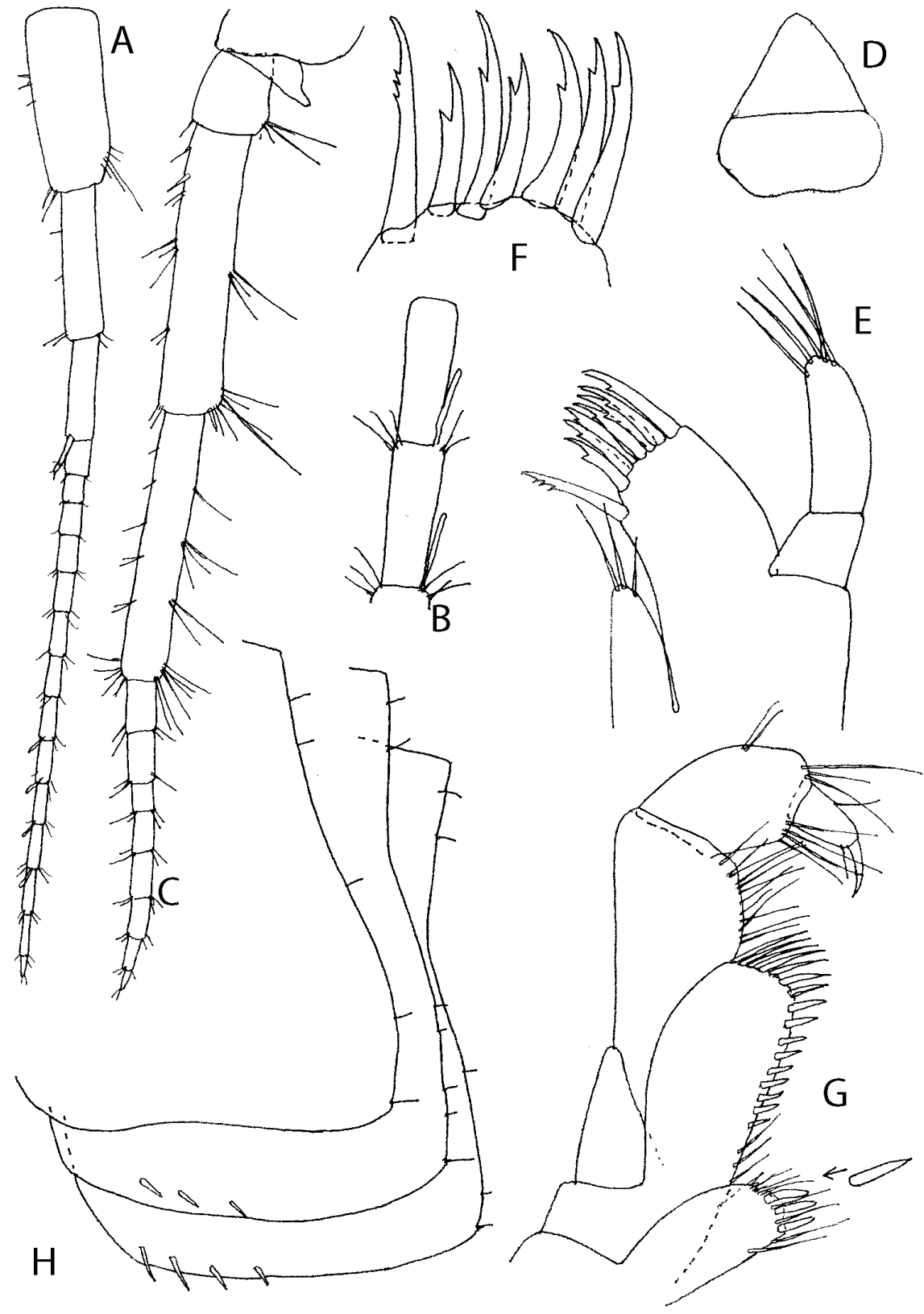

Fig. 1. Niphargus (Orniphargus) lourensis skirosi, ssp. n., male $8.0 \mathrm{~mm}$, Skiros Island, Molos (G-213): $\mathrm{A}=$ antenna $1 ; \mathrm{B}=$ aesthetasc on antenna 1-flagellum; $\mathrm{C}=$ antenna 2; $\mathrm{D}=$ labrum; $\mathrm{E}=$ maxilla $1 ; \mathrm{F}=$ outer plate of maxilla $1 ; \mathrm{G}=$ maxilliped; $\mathrm{H}=$ epimeral plates $1-3$. 


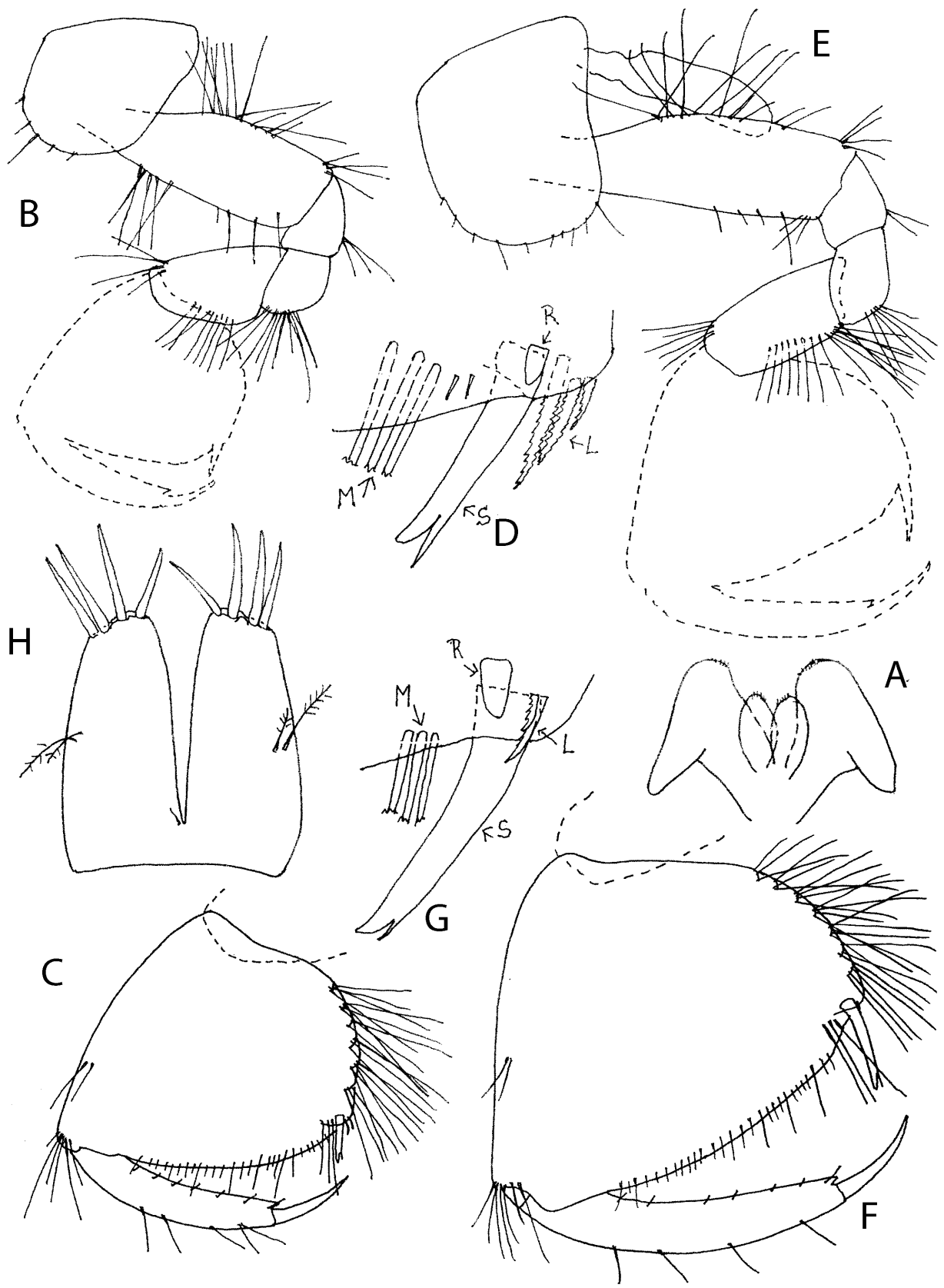

Fig. 2. Niphargus (Orniphargus) lourensis skirosi, ssp. n., male $8.0 \mathrm{~mm}$, Skiros Island, Molos (G-213): $\mathrm{A}=$ labium; $\mathrm{B}=$ gnathopod 1; $\mathrm{C}=$ gnathopod 1-propodus, outer face; $\mathrm{D}=$ distal corner of gnathopod 1-propodus, inner face [S= corner $\mathrm{S}$ spine; $\mathrm{L}=$ lateral serrate $\mathrm{L}$-spines; $\mathrm{R}=$ subcorner spine; $\mathrm{M}=$ facial $\mathrm{M}$-setae]; $\mathrm{E}=$ gnathopod 2, outer face; F= gnathopod 2-propodus, outer face; $\mathrm{G}=$ distal corner of gnathopod 2-propodus, inner face [S= corner S-spine; $\mathrm{L}=$ lateral serrate $\mathrm{L}$ spines; $\mathrm{R}=$ subcorner spine; $\mathrm{M}=$ facial $\mathrm{M}$-setae]; $\mathrm{H}=$ telson. 
Gnathopods 1-2 are moderately large, with propodus larger than corresponding coxa (fig. 2B, E). Gnathopod 1: article 2 with long setae along anterior and posterior proximal margin, and shorter setae at distal anterior and posterior margin; article 3 at posterior margin with one bunch of setae (fig. 2B). Article 5 is shorter than propodus (ratio: 37:53), along anterior margin with one distal bunch of setae. Propodus is trapezoid, poorly longer than broad (ratio: 74:69), along posterior convex margin with 6 transverse rows of setae (fig. 2C). Palm is slightly convex, inclined hardly over half of propodus-length, defined on outer face by one corner S-spine accompanied laterally by 3 serrate L-spines and 3 facial M-setae, on inner face by one subcorner R-spine (fig. 2D). Dactylus reaching posterior margin of propodus, along outer margin with 5 median setae, along inner margin with row of several short setae (fig. 2C).

Gnathopod 2 is remarkably larger than gnathopod 1 (fig. 2B, E). Article 2 along anterior margin with several short setae in distal part, and no setae in proximal part; along posterior margin are attached numerous long setae in proximal part, and several short setae in distal part. Article 3 at posterior margin with one bunch of setae. Article 5 is shorter than propodus (ratio: 43:68), at anterior margin with distal bunch of setae (fig. 2E). Propodus is trapezoid, hardly broader than long (ratio: 94:91), along posterior margin with 7 transverse rows of setae (fig. 2F). Palm is convex, remarkably inclined over 2/3 of propodus-length, defined on outer face by one S-spine and 3 facial M-setae, on inner face by 2 slender L-spines sitting partially behind S-spine, and by one subcorner R-spine (fig. 2G). Dactylus reaching posterior margin of propodus, at outer margin with 4 median setae, along inner margin with several short setae (fig. 2F).

Pereopods 3 and 4 are moderately slender. Pereopod 3: article 2 at anterior margin with 2 proximal long setae and 3 short distal setae, along posterior margin with numerous long setae (fig. 3A). Articles 4-6 are of unequal length (ratio: 55:40:47); article 4 at anterior and posterior margin with several setae not exceeding diameter of article itself; article 5 along posterior margin with 4 spines and single short setae; article 6 along posterior margin with 6 groups of single or pairs of short spines. Dactylus is moderately slender, much shorter than article 6 (ratio: 16:47), at outer margin with one median plumose seta, at inner margin with one very slender spine near basis of the nail (fig. 3B); nail is hardly shorter than pedestal (ratio: 21:23).

Pereopod 4: article 2 at anterior margin with 2 proximal long setae and 3 mediodistal short setae; along posterior margin with numerous longer proximal setae and several mediodistal short setae. Articles 4-6 are of unequal length (ratio: 51:38:47): article 4 at anterior margin with 3-4 setae, at posterior margin with 4-5 bunches of 1-2 short setae; article 5 at anterior margin with 2 groups of short setae, at posterior margin with 3 single short spines and seta; article 6 along posterior margin with 5 bunches of short spines (fig. 3C). Dactylus is much shorter than article 6 (ratio: 20:47), at inner margin with one very slender spine near basis of the nail, at outer margin with one median plumose seta (fig. 3D), nail is hardly shorter than pedestal (ratio: 23:25). 


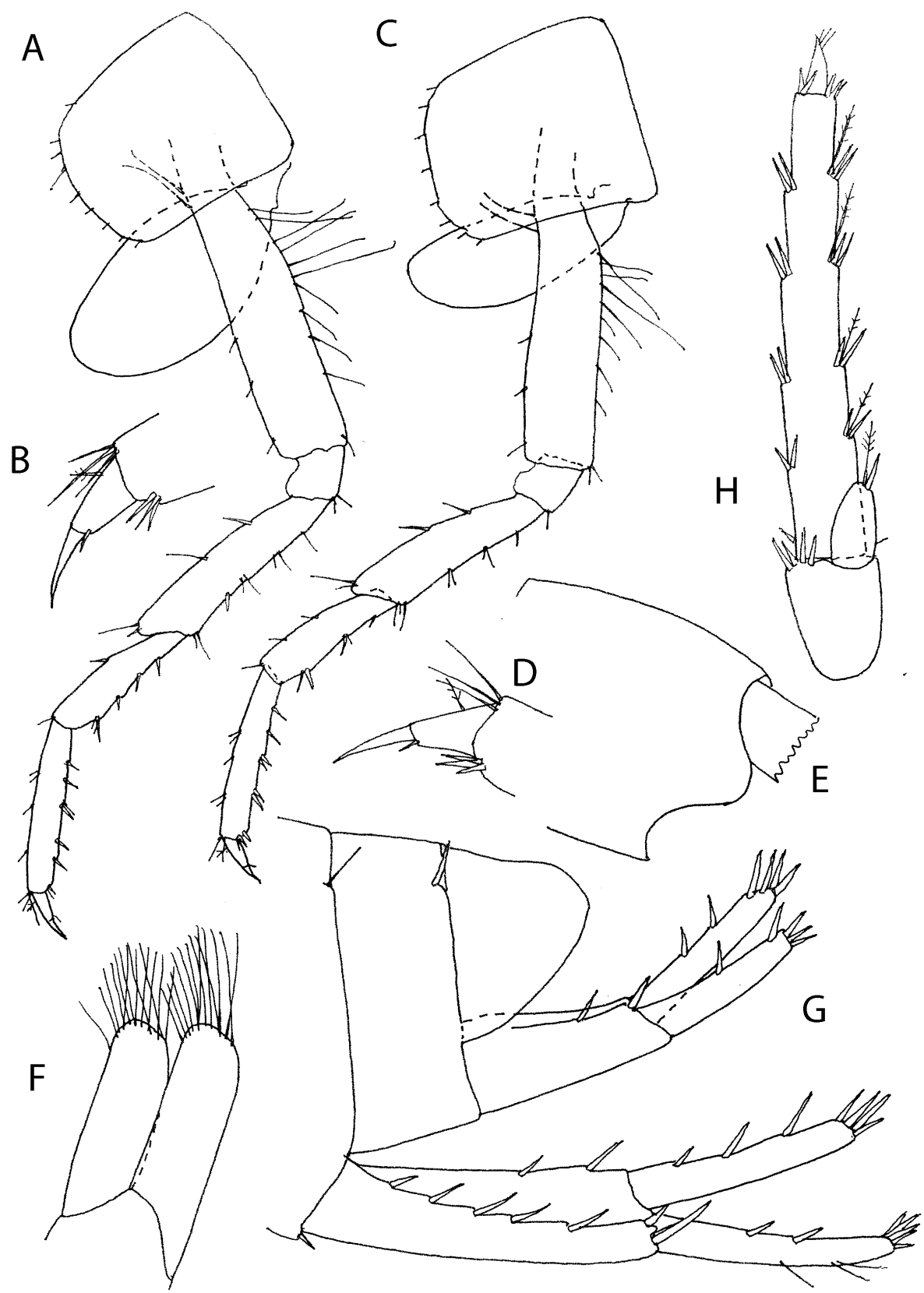

Fig. 3. Niphargus (Orniphargus) lourensis skirosi, ssp. n., male $8.0 \mathrm{~mm}$, Skiros Island, Molos (G-213): $\mathrm{A}-\mathrm{B}=$ pereopod $3 ; \mathrm{C}-\mathrm{D}=$ pereopod $4 ; \mathrm{E}=$ head; $\mathrm{F}=$ maxilla 2; $\mathrm{G}=$ urosome with uropods 1-2; $\mathrm{H}=$ uropod 3. 


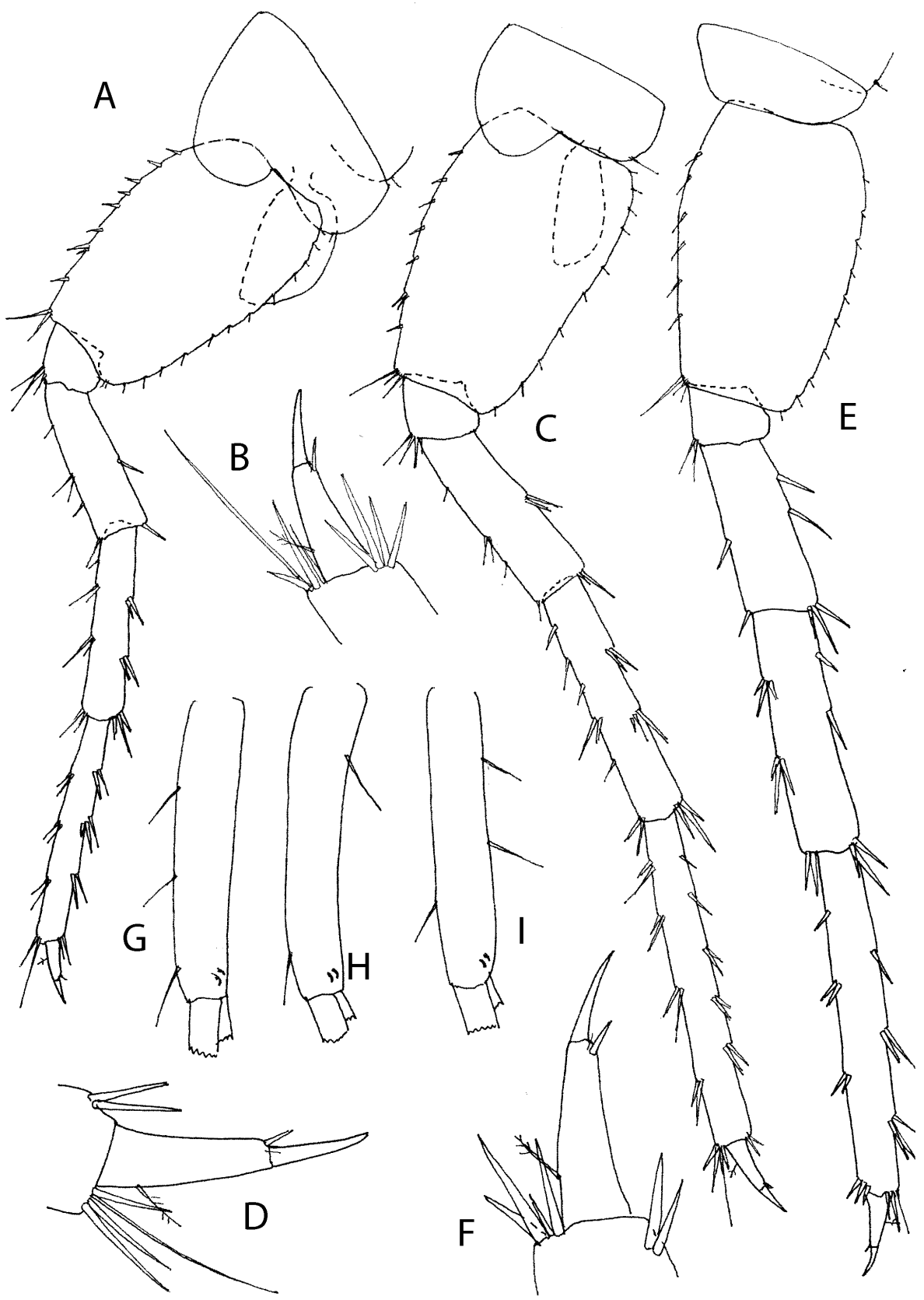

Fig. 4. Niphargus (Orniphargus) lourensis skirosi, ssp. n., male $8.0 \mathrm{~mm}$, Skiros Island, Molos (G-213): A-B= pereopod 5; $\mathrm{C}-\mathrm{D}=$ pereopod 6; $\mathrm{E}-\mathrm{F}=$ pereopod 7; $\mathrm{G}=$ peduncle of pleopod $1 ; \mathrm{H}=$ peduncle of pleopod 2; I= peduncle of pleopod 3 . 
Pereopods 5-7 are moderately long. Pereopod 5 is remarkably shorter than pereopods 6 and 7, with article 2 dilated, longer than broad (ratio: 73:46), along anterior convex margin are attached nearly 9-10 short spines, along posterior poorly convex margin are attached nearly 14 short setae, ventroposterior lobe is not developed (fig. 4A). Articles 4-6 are of unequal length (ratio: 44:52:61): article 4 at anterior margin with a row of short strong setae, at posterior margin with 2 single short spines; article 5 at anterior margin with 3 groups of slender spines and setae, at posterior margin with 3 bunches of spines; article 6 along posterior margin with 4 bunches of spines, along anterior margin with 4 groups of strong setae and one long distal seta. Article 2 is longer than article 6 (ratio: 73:61). Dactylus is much shorter than article 6 (ratio: 19:61), moderately slender, at inner margin with one slender spine, at outer margin with one median plumose seta (fig. 4B); nail is shorter than pedestal (ratio: 21:33).

Pereopod 6: article 2 is remarkably longer than broad (ratio: 79:50), along anterior margin with 8 groups of spines, along posterior margin with 10 short setae, ventroposterior lobe absent (fig. 4C). Articles 4-6 of unequal length (ratio: 55:69:88), article 4 along posterior margin with 2 groups of short spines; article 5 along anterior margin with 6 groups of short spines, along posterior margin with 3 groups of spines; article 6 along anterior and posterior margin with several bunches of spines; at tip are attached several spines and one long distal seta. Article 2 is shorter than article 6 (ratio: 79:88). Dactylus is much shorter than article 6 (ratio: 23:88), at inner margin with one slender spine near basis of the nail, at outer margin with one median plumose seta (fig. 4D); nail is shorter than pedestal (ratio: 27:48).

Pereopod 7: article 2 is longer than broad (ratio: 78:48), along anterior margin with 7 spines, along posterior slightly convex margin appear nearly 10 short setae, ventroposterior lobe absent (fig. 4E). Articles 4-6 are of unequal length (ratio: 48:65:93), along anterior and posterior margin with single or bunches of spines. Article 2 is shorter than article 6 (ratio: 78:93). Dactylus is moderately slender, along inner margin with one spine near basis of the nail, along outer margin with one median plumose seta (fig. 4F); nail is shorter than pedestal (ratio: 25:50).

Pleopods 1-3 are with 2 retinacula each. Peduncle of pleopod 1 along anterior margin with 3 long setae (fig. 4G); peduncle of pleopod 2 with one distal seta at anterior margin (fig. 4H); peduncle of pleopod 3 at anterior margin with one distal seta, along posterior margin with 2-3 long simple setae (fig. 4 I).

Uropod 1: peduncle longer than rami, with dorsoexternal row of strong spines; dorsointernal row is consisting on one median and one distal spine (fig. 3G). Outer ramus is as long as inner one or hardly longer, provided with 2 lateral and 5 distal short spines, as well as with 3 simple setae along outer margin; inner ramus is provided with 3 strong lateral and 4 distal spines.

Uropod 2: inner ramus is hardly longer than outer one, both rami with 1-2 single lateral and 4 distal short spines (fig. 3G). 
Uropod 3 is relatively short; peduncle nearly as long as broad, with several distal spines; inner ramus is short, with one distal spine and plumose seta; outer ramus is consisting of 2 articles: first article is relatively slender, along outer margin with 5 bunches of short spines, along inner margin with 5 bunches of short spines mixed with single short plumose setae (fig. $3 \mathrm{H}$ ); distal article is short, not exceeding diameter of first article and provided with 3 short distal simple setae.

Telson is relatively short, slightly longer than broad (ratio: 70:64), incised over $3 / 4$ of telson-length; each lobe with 4 distal spines shorter than half of telsonlength; a pair of short plumose setae is attached in the middle of outer margin of telson (fig. 2H).

Coxal gills are relatively short, not reaching the ventral margin of corresponding article 2 of the legs (figs. 2E, 3A, C; 5A, C). Coxal gills on pereopod 3 are larger than these of pereopod 4 .

FEMALE 7.0 mm with setose oostegites (from G-218) (slides G-218/1, 218/2, 218/3)

Head and body are very similar to the males, metasomal segments 1-3 with 4 dorsoposterior marginal setae each (fig. 6B). Urosomal segment 1 on each dorsolateral side with one seta, urosomal segment 2 on each dorsolateral side with one spine; urosomal segment 3 naked. Urosomal segment 1 on each ventroposterior corner with one short spine near basis of uropod 1-peduncle (fig. 6 I).

Epimeral plates are angular: epimeral plate 1 with slightly concave ventral margin, ventroposterior corner is distinctly marked, defined with corner seta, along posterior slightly convex margin appear several setae only (fig. 6B). Epimeral plate 2 is with hardly convex posterior margin provided with several setae only, ventral margin is slightly convex, with 3 subventral spines and well marked ventroposterior corner. Epimeral plate 3 is distinctly angular or slightly acute, with nearly straight and inclined posterior margin provided with 4 short setae, along ventral convex margin are attached 4 submarginal spines (fig. 6B).

Antenna 1 reaching nearly half of body, main flagellum is consisting of 19 articles. Accessory flagellum is 2-articulate, not reaching half of peduncular article 3-length. Flagellum of antenna 2 is longer than last peduncular article and consisting of 9 articles.

Mouthparts mainly like these in male. Mandibular palpus is similar to that in male. Maxilla 1 inner plate with 2-3 setae, outer plate with 7 spines [6 spines with one lateral tooth, one (mesial) spine with 5 lateral teeth (fig. 6A); palpus 2articulated, provided with 5-7 setae.

Maxilliped inner plate is provided with 4 distal pointed spines and several setae, outer plate hardly exceeding half of palpus article 2 and provided with nearly 13 distomesial spines; palpus article 3 at outer margin with one median and one distal group of setae; palpus article 4 at inner margin with 1-2 setae near basis of the nail. 




Fig. 5. Niphargus (Orniphargus) lourensis skirosi, ssp. n., male $8.0 \mathrm{~mm}$, Skiros Island, Molos (G-213): $A=$ incisor, lacinia mobilis and rakers of right mandible; $B=$ mandibular palpus, outer face $[\mathrm{A}=$ outer facial $\mathrm{A}$-setae; $\mathrm{D}=$ marginal $\mathrm{D}$-setae; $\mathrm{E}=$ distal $\mathrm{E}$-setae]; $\mathrm{C}=$ mandibular palpus article 3, inner face [facial B-setae, other setae omitted];

Female, 7.0 mm, Skiros Island, Aspous (G-218): D-E= gnathopod 1, outer face; F-G= gnathopod 2-propodus, outer face; $\mathrm{H}=$ distal corner of gnathopod 2-propodus, inner face [S= corner S-spine; $\mathrm{L}=$ lateral serrate $\mathrm{L}$-spines; $\mathrm{R}=$ subcorner $\mathrm{R}$-spine; $\mathrm{M}=$ facial $\mathrm{M}$ setae]; I= coxa 3; $\mathrm{J}=$ coxa 4. 


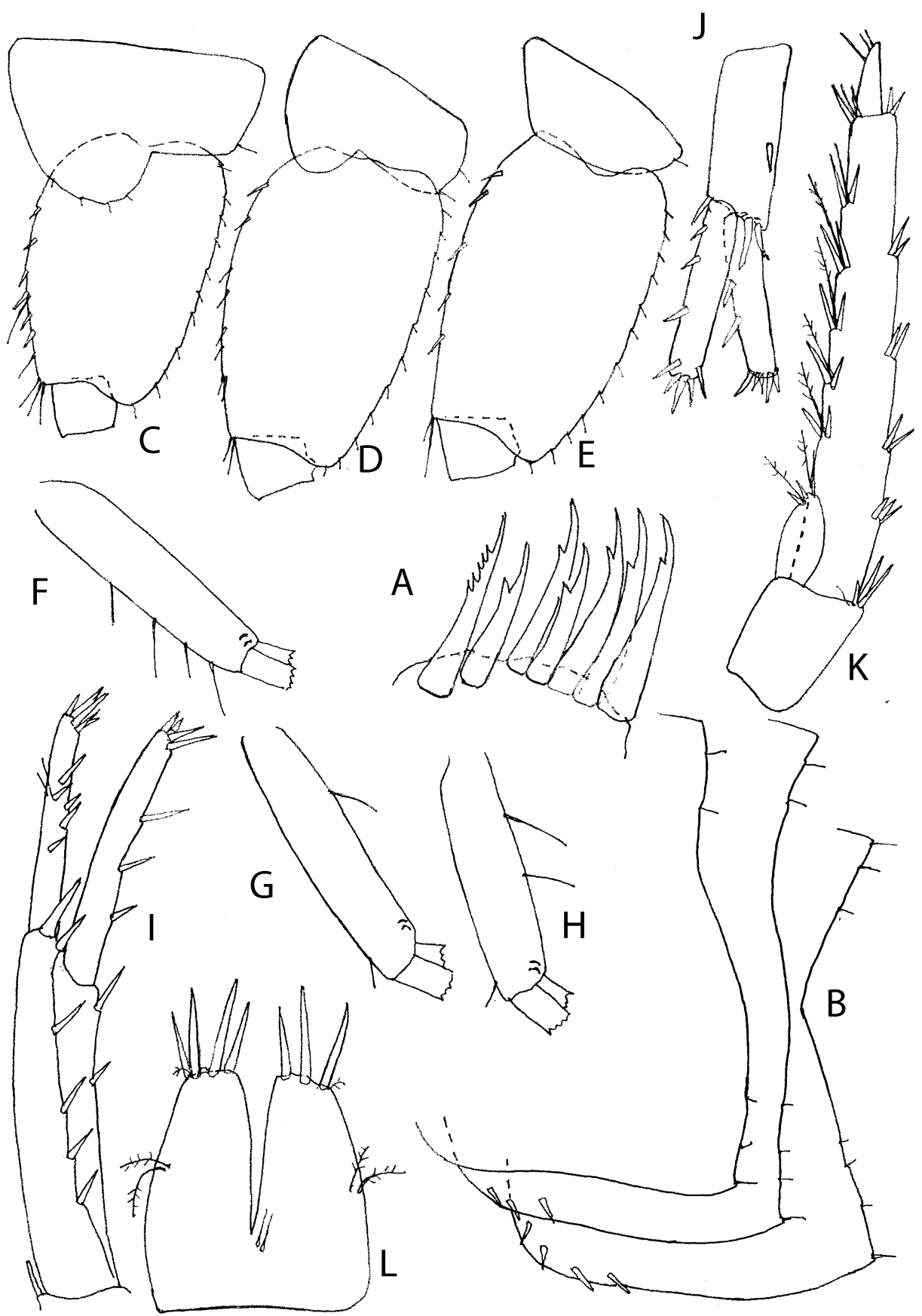

Fig. 6. Niphargus (Orniphargus) lourensis skirosi, ssp. n., female $7.0 \mathrm{~mm}$, Skiros Island, Espouse (G-218): $A=$ maxilla 1, outer plate; $B=$ epimeral plates 1-3; $C=$ pereopod 5 basipodit; $\mathrm{D}=$ pereopod 6 basipodit; $\mathrm{E}=$ pereopod 7 basipodit; $\mathrm{F}=$ pleopod 1 peduncle; $\mathrm{G}=$ pleopod 2 peduncle; $\mathrm{H}=$ pleopod 3 peduncle; I- uropod 1; J= uropod 2; $\mathrm{K}=\operatorname{uropod} 3$; $\mathrm{L}=$ telson. 
Coxae are rather similar to these in male. Coxa 1 is broader than long (ratio: 40:36), with subrounded non produced ventroanterior corner provided with nearly 6 marginal setae (fig. 5D). Coxa 2 is longer than broad (ratio: 55:45), with subrounded ventroanterior corner provided with nearly 10 unequal setae (fig. 5F). Coxa 3 is longer than broad (ratio: 60:48) along ventral convex margin appear nearly 10 setae (fig. $5 \mathrm{I}$ ). Coxa 4 is only slightly longer than broad (ratio: 60:52), with convex ventral margin bearing nearly 9 setae, posterior margin is slightly concave, ventroposterior lobe absent (fig. 5J).

Coxa 5 is only slightly shorter than coxa 4 , bilobed, broader than long (ratio: 70:44), anterior lobe is subrounded (fig. 6C). Coxa 6 is distinctly smaller than coxa 5, bilobed, broader than long (ratio: 52:35) (fig. 6D). Coxa 7 is entire, smaller than coxa 6, broader than long (ratio: 52:23) (fig. 6E).

Gnathopods 1 and 2 are rather smaller than these in male, with propodus nearly as large and corresponding coxa (fig. 5D, F).

Gnathopod 1 is remarkably smaller than gnathopod 2, article 2 along anterior margin with a row of long setae in proximal part and 2 short setae in distal part; along posterior margin appears one group of long setae in proximal part (fig. 5D); article 3 with one bunch of setae at posterior margin. Article 5 is shorter than propodus (ratio: 53:69), at anterior margin with one distal bunch of setae (fig. 5E). Propodus is trapezoid, hardly longer than broad (ratio: 69:65), along posterior margin with 5 transverse rows of setae (fig. 5E). Palm is convex, inclined nearly half of propodus-length, defined on outer face by one corner Sspine accompanied laterally by 3 slender L-spines and 3 facial M-setae, on inner face by one subcorner R-spine. Dactylus reaching posterior margin of propodus, provided with 4 median setae along outer margin and several short setae at inner margin (fig. 5E).

Gnathopod 2: article 2 along anterior margin with 3 short setae in distal part only (fig. 5F), along posterior margin with numerous long setae in proximal part and single short setae in distal part; article 3 at posterior margin with one bunch of setae (fig. 5F. Article 5 is shorter than propodus (ratio: 63:82), along anterior margin with distal bunch of setae (fig. 5G). Propodus is trapezoid, nearly as long as broad, along posterior margin with 7 transverse rows of setae (fig. 5G). Palm is convex, inclined nearly half of propodus-length, defined on outer face by one corner S-spine, 1-2 L-spines are sitting very close to the S-spine, not behind S-spine (fig. $5 \mathrm{H}$ ), on outer face are attached 2-3 facial M setae; one subcorner short R-spine appear at inner face. Dactylus is reaching posterior margin of propodus, along outer margin with 3 median setae, along inner margin with several short setae (fig. 5G).

Pereopods 3-4 are similar to males, with short dactylus bearing one slender spine-like seta at inner margin near basis of the nail and one median plumose seta at outer margin; nail is shorter than pedestal.

Pereopods 5-7 are rather similar to males in shape and armature, and we figured here the basipodites (article 2) only. Pereopod 5: article 2 is rather longer than broad (ratio: 73:50), along anterior convex margin appear a row of short spines accompanied with several short setae or these setae are missing (fig. 6C), 
along posterior poorly convex margin are attached nearly 11 setae, ventroposterior lobe is not fully developed, ventroanterior corner is not produced (fig. 6C). Along inner margin of dactylus appears one slender spine near basis of the nail.

Pereopod 6: article 2 is remarkably larger than that of pereopod 5, longer than broad (ratio: 84:52), along anterior margin with row of short spine-like setae, along posterior convex margin with nearly 12 setae, ventroposterior lobe is not fully developed (fig. 6D); at inner margin of dactylus appear one slender spine near basis of the nail.

Pereopod 7: article 2 is longer than broad (ratio: 83:52), along anterior slightly convex margin with 5-6 slender spines, along posterior margin with nearly 12 setae, ventroposterior lobe is not distinctly developed (fig. 6E).

Pleopods 1-3 are provided with 2 retinacula each. Peduncle of pleopod 1 at anterior margin is with 4 setae (fig. 6F); peduncle of pleopod 2 along anterior margin with one distal seta, at posterior margin with one proximal seta (fig. 6G). Peduncle of pleopod 3 at anterior margin is with one short distal seta, at posterior margin with 2 medial long setae (fig. $6 \mathrm{H}$ ).

Uropod 1: peduncle is rather longer than rami, with dorsoexternal row of strong spines, at dorsointernal side with one distal and one median strong spine (fig. 6 I); rami are of equal length, with several lateral spines and 4-5 distal short spines; 2 short simple setae are attached in the middle of outer ramus.

Uropod 2: peduncle is with one median and several distal spines; rami are almost of the same length, provided with several lateral and 5 distal short spines (fig. 6J).

Uropod 3 like that in male, relatively short: peduncle is short, with several distal spines; inner ramus is short, scale-like, with distal 2 spines and one plumose seta (fig. 6K). Outer ramus is 2-articulated: along outer margin appear 5 bunches of short spines, along inner (mesial) margin are attached 7 bunches of short spines accompanied by single plumose setae; second article is short, not exceeding diameter of first article and provided with 3 distolateral small simple setae.

Telson is relatively short, hardly longer than broad (ratio: 67:60), lobes are with 3 and 4 distal spines shorter than half of telson-length; a pair of short plumose setae is attached near the middle of outer margin of each lobe (fig. 6L).

Coxal gills are relatively small, not reaching ventral tip of corresponding article 2 (fig. 5F). Oostegites are broad, with short marginal setae (fig. 5F).

\section{VARIABILITY}

Urosomal segment 1 is always with one seta at each dorsolateral side; urosomal segment 2 on each dorsolateral side always with one strong spine.

Maxilla 1: inner plate is with 2-3 setae, outer plate with 7 spines [6 spines with one lateral tooth, mesial spine with 3-5 lateral teeth], only exceptionally one additional lateral tooth appear on one spine only [5-1-2-1-1-1-1]; palpus hardly exceeding basis of outer plate-spines, provided with 5-7 setae. 
Maxilliped inner plate with 3-4 distal pointed spines accompanied by single setae. Additional A-seta on outer face of mandibular palpus article 3 is sometimes absent. Accessory flagellum is shorter than half of peduncular article 3 of antenna 1.

On palm of gnathopod 2-propodus appear 1-2 serrate L-spines sitting only partially behind S-spine or almost laterally of S-spine.

Three L-spines on gnathopod 1- propodus are sitting always laterally of corner S-spine.

Lobes of telson are provided with 3-4 distal spines distinctly shorter than half of telson-length; usually both lobes of telson are provided with 4 spines, sometimes one lobe with 3 and other with 4 spines, rarely both lobes were with 3 spines only.

G-222 (Skiros, Linaria), male $6.0 \mathrm{~mm}$ : This specimen agrees mainly with holotype. Urosomal segment 1 with one seta on each dorsolateral side; urosomal segment 2 with one strong spine on each dorsolateral side, urosomal segment 3 naked.

Maxilla 1: inner plate with 2 setae, outer plate with 7 spines [6 spines with one lateral tooth, one spine with 4-5 teeth), palpus with 5 distal setae. Maxilliped inner plate with 4 distal pointed spines, palpus article 4 at ventral margin with one seta near basis of the nail.

Palm of gnathopod 1- propodus with 3 serrate L-spines sitting laterally of corner S-spine. Gnathopod 2- propodus: palm with serrate L-spines sitting laterally or only partially behind corner S-spine, like that in female (fig. $5 \mathrm{H}$ ). Lobes of telson are with 4 relatively short distal spines not reaching half of telson-length.

HOLOTYPE: male 8.0 mm (from G-213) (slides: 213/1, 213/2, 213/3). Holotype is deposited in KARAMAN`s Collection in Podgorica, Montenegro.

LOCUS TYPICUS: Molos, radar station, Skiros Island (Aegean Sea, Greece).

DISTRIBUTION: Skiros Island, Aegean Sea, Greece.

DERIVATIO NOMINIS: The name "skirosi" is made according to the name of locality, Skiros Island, where the taxon was collected.

\section{REMARKS AND AFFINITIES.}

Fišer et al. (2006) described a new species Niphargus lourensis from the subterranean waters of spring of Louros River, Vouliasta, Ioannina [Epirus, Greece] based on one adult female of $15 \mathrm{~mm}$ belonging to the subgenus Orniphargus S. Kar. 1950 (Karaman, S. 1950a, 1950b).

The holotype of Niphargus lourensis from type-locality [female $15 \mathrm{~mm}$ in final stage] differs from our populations of Skiros island in Aegean Sea by large body-size, very long distal spines on telson, by elevated number of spines on urosomal segments [2 spines on each side of urosomal segment 1, 4 spines on each side of urosomal segment 2], by very spinose outer ramus of uropod 3, by rather narrowed article 2 of pereopods 5-7 in female, by presence of one serrate 
L-spine sitting completely behind corner S-spine on palm of gnathopod 2propodus, by outer plate of maxilla 1 "with 7 uni-, bi- or pluri-toothed spines".

The variability of taxonomic characters and male of $N$. lourensis from type-locality remains unknown, because neither other localities nor redescription of this species were published later. By this way it is very difficult to understand the real value of established taxonomical differences between type-locality specimen and specimens from Skiros Island. Based on above mentioned taxonomic characters and zoogeographical data, we consider useful to describe the specimens from Skiros Island as not identical with these from Vouliasta, but as a distinct new subspecies, Niphargus (Orniphargus) lourensis skirosi, ssp. n., with above mentioned differences.

The further discovery of this species in type locality and other localities will probably put more light on the taxonomical relations between populations of these two distant localities, including the possibility that the populations from Skiros can be within extreme limits of the variability of $N$. lourensis.

The other known member of the subgenus Orniphargus known from Greece is Niphargus lindbergi S. Karaman 1956, described and known from Spilia Draconera Cave, Attica, Greece (Karaman, S. 1956), but this species differs remarkably from ssp. skirosi by presence of lateral spines on lobes of telson, by elevated number of retinacula on pleopods, presence of 2 spines at ventroposterior corner of urosomal segment 1 near basis of uropod 1-peduncle, etc. (see below).

In the adjacent region of Macedonia two species of Niphargus (Orniphargus) subgenus are present: Niphargus macedonicus S. Karaman 1929 (loc. typ.: Rašće spring near Skoplje) and Niphargus pellagonicus S. Karaman 1943 (loc. typ.: spring on road from Bitola towards the village Magarevo), but both these species differ from ssp. skirosi by elevated number of retinacula on pleopods 1-3 and various other morphological characters.

\section{NIPHARGUS (ORNIPHARGUS) LINDBERGI S. Karaman 1956 Figures 7-9}

Niphargus (Orniphargus) lindbergi, S. Karaman 1956: 1, figs. 1-6;

Niphargus lindbergi G. Karaman 1972: 7; Barnard, J. \& Barnard, C. 1983: 692;

G. Karaman \& Ruffo 1986: 527: Fišer et al. 2006: 2315;

?Niphargus lindbergi, Pesce \& Maggi, 1983: 58.

MATERIAL EXAMINED: GREECE

Sp. $424(\mathrm{G}-231)=$ Spilia Draconera Cave, Attica, 29.4 .1954 (leg. K. Lindberg); one male $12 \mathrm{~mm}$ partially dissected, and slides 231/1, 231/2 (HOLOTYPE);

S-6361 (G-88)= Thessaly (=Tessalia), spring on main road Lamia-Larissa (=Laritza), water temp. $14 * \mathrm{C}$, pH 6.7; $\mathrm{NO}_{2} 1 \mathrm{mg} / \mathrm{l}, 11.5 .1977$ (leg. Pesce, Maggi \& Miranda); male $6.0 \mathrm{~mm}$. 


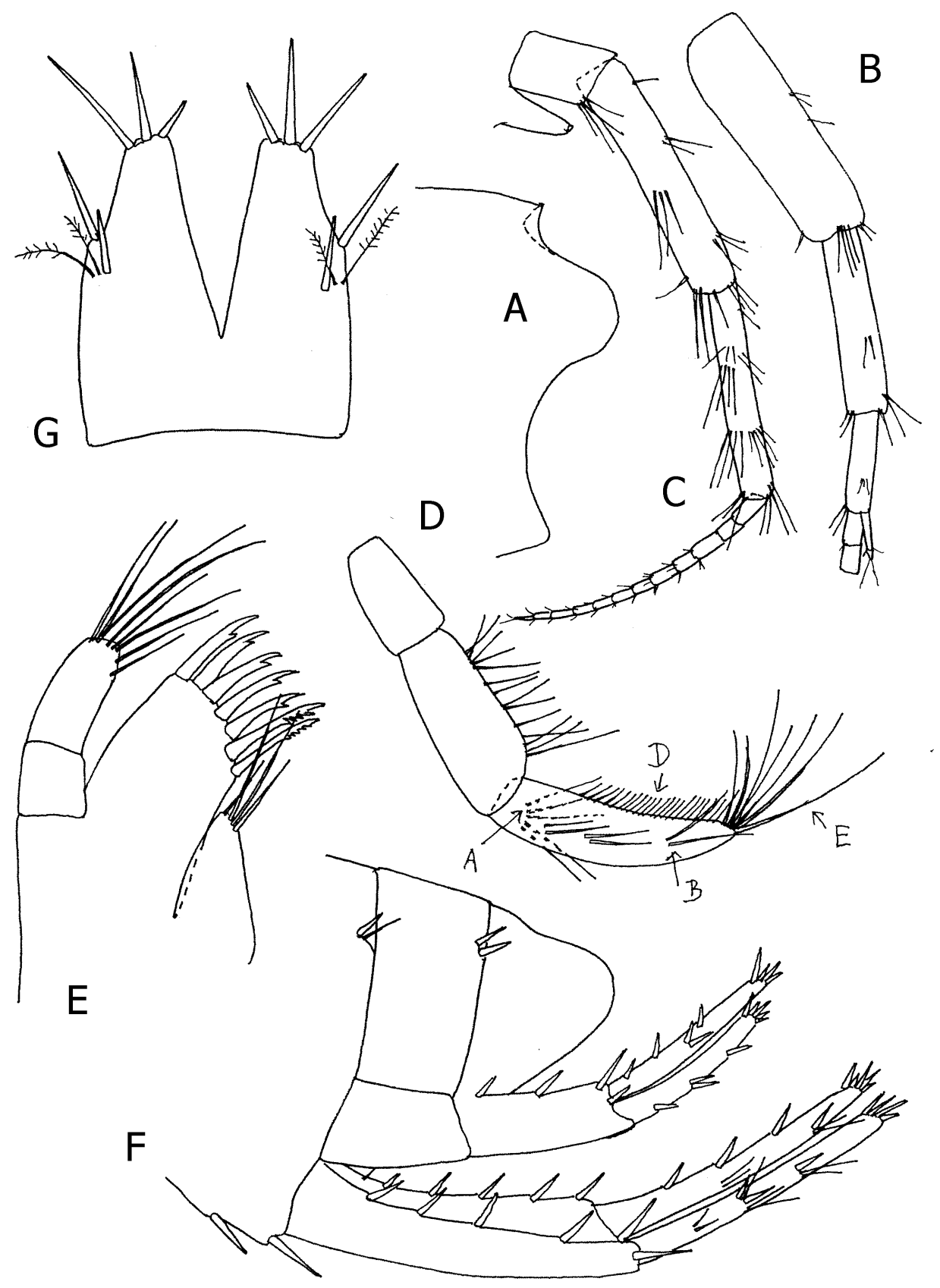

Fig. 7. Niphargus (Orniphargus) lindbergi S. Karaman 1956, male $12.0 \mathrm{~mm}$, Draconera Cave (holotype): $\mathrm{A}=$ lateral cephalic lobe; $\mathrm{B}=$ peduncle of antenna 1 ; $\mathrm{C}=$ antenna $2 ; \mathrm{D}=$ mandibular palpus, inner face $[\mathrm{A}=$ facial $\mathrm{A}$-setae; $\mathrm{B}=$ facial $\mathrm{B}$ setae; $\mathrm{D}=$ marginal $\mathrm{D}$-setae; $\mathrm{E}=$ distal $\mathrm{E}$-setae]; $\mathrm{E}=$ maxilla $1 \mathrm{~F}=$ urosome with uropods 1-2; G= telson. 


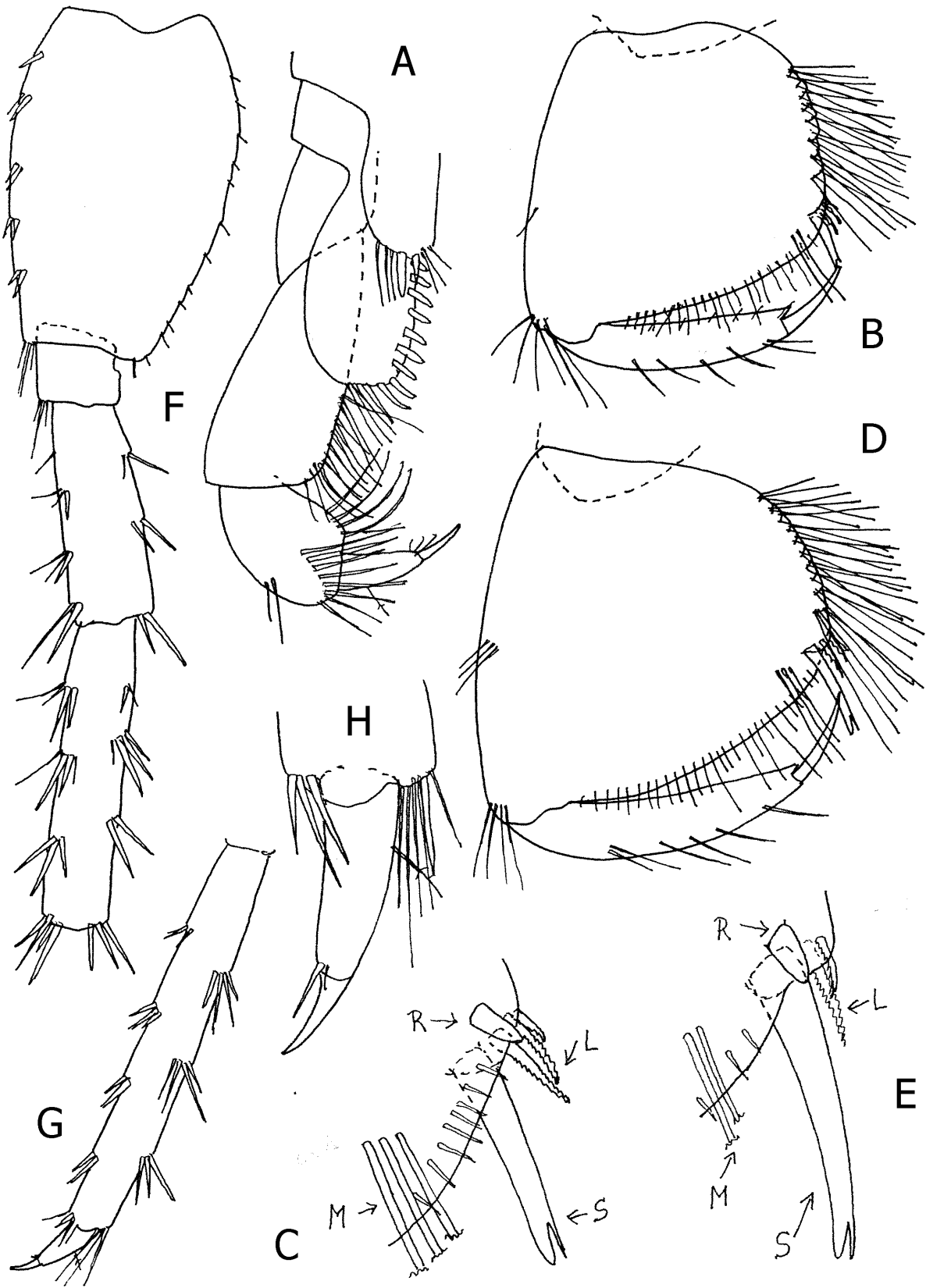

Fig. 8. Niphargus (Orniphargus) lindbergi S. Karaman 1956, male $12.0 \mathrm{~mm}$, Draconera Cave (holotype): $\mathrm{A}=$ maxilliped; $\mathrm{B}=$ gnathopod 1 propodus, outer face; $\mathrm{C}=$ distal corner of gnathopod 1-propodus, inner face [S= corner $\mathrm{S}$-spine; $\mathrm{L}=$ lateral serrate $\mathrm{L}$-spines; $\mathrm{R}=$ subcorner $\mathrm{R}$-spine; $\mathrm{M}=$ facial $\mathrm{M}$-setae]; $\mathrm{D}=$ gnathopod 2-propodus, outer face; $\mathrm{E}=$ distal corner of gnathopod 2-propodus, inner face $[\mathrm{S}=$ corner $\mathrm{S}$-spine; $\mathrm{L}=$ lateral serrate $\mathrm{L}$-spines; $\mathrm{R}=$ subcorner $\mathrm{R}$-spine; $\mathrm{M}=$ facial $\mathrm{M}$-setae]; $\mathrm{F}-\mathrm{G}=$ pereopod 7; $\mathrm{H}=$ dactylus of pereopod 7 

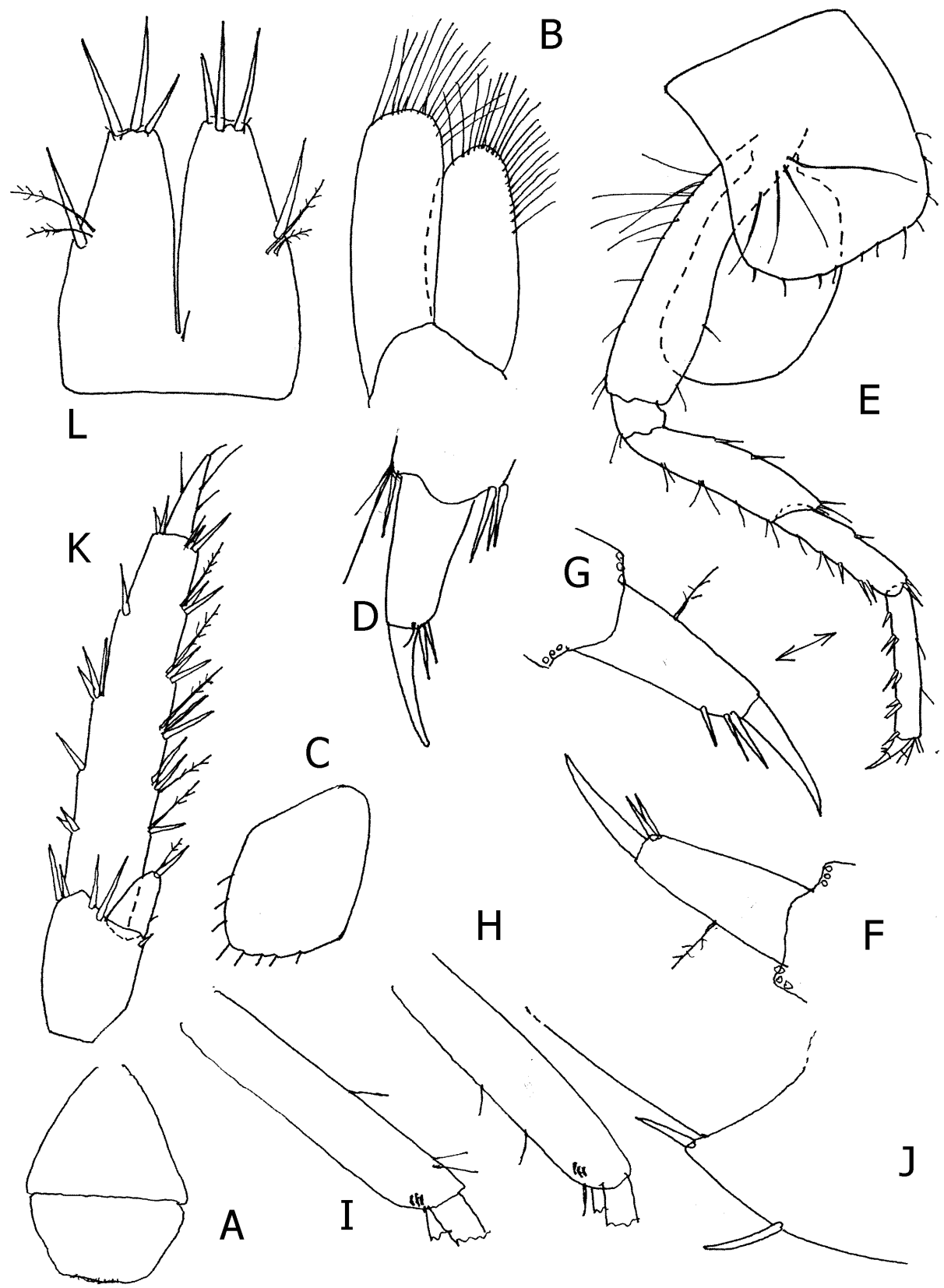

A

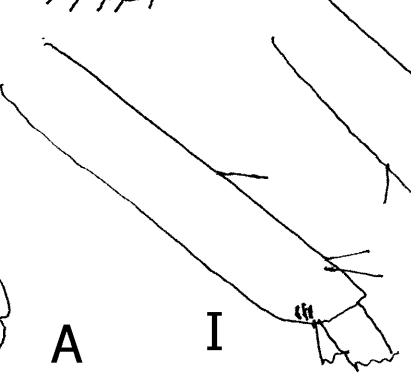

$\mathrm{H}$



F

Fig. 9. Niphargus (Orniphargus) lindbergi S. Karaman 1956, male $12.0 \mathrm{~mm}$, Draconera Cave (holotype): $\mathrm{A}=$ labrum; $\mathrm{B}=$ maxilla 2 ; $\mathrm{C}=\operatorname{coxa} 1 ; \mathrm{D}=$ dactylus of pereopod 3; $\mathrm{E}=$ pereopod $4 ; \mathrm{F}-\mathrm{G}=$ left and right dactylus of pereopod $4 ; \mathrm{H}=$ pleopod 1 peduncle; I= pleopod 3-peduncle;

Male juv. 6.0 mm, Thessaly: $\mathrm{J}=$ urosomal segment 1 , ventroposterior corner; $\mathrm{K}=$ uropod 3; L= telson. 
DIAGNOSIS (males only): Moderately strong body, mesosomal segments smooth; metasomal segments 1-3 with dorsoposterior single setae; urosomal segments 1-2 with spines; telson with distal, marginal and 0-1 facial spines. Urosomal segment 1 on each ventroposterior corner with 2 strong single spines. Epimeral plates slightly acute. Maxilla 1 is provided with 4 setae, outer plate with 7 spines (most of them with one lateral tooth), palpus short, with numerous distal setae. Maxilliped inner plate short, with 3 distal spines.

Coxae 2-4 are slightly longer than broad, coxa 1 shallow, rhomboid, coxa 4 without distinct ventroposterior lobe, coxa 5 slightly shorter than coxa 4 . Gnathopods 1-2 moderately strong, with trapezoid propodus having inclined palm bearing L-spines sitting laterally of corner S-spine, and dactylus with row of setae along outer margin. Pereopods 5-7 with unlobed article 2; dactylus of pereopods 3-7 strong, with one spine at inner margin (exceptionally with additional spine on pereopods 3 or 4). Pleopods with elevated number of retinacula, peduncles scarcely setose. Uropod 1 with equal rami; uropod 2 with inner ramus poorly longer than outer one. Uropod 3 short, with first article of outer ramus spinose, second article short. Lobes of telson are with distal; outer marginal and 0-1 facial spine.

\section{DESCRIPTION of holotype (male $12.0 \mathrm{~mm}$ ):}

Stanko Karaman (1956) described and partially figured this species based on one adult male of $12 \mathrm{~mm}$. We added some unknown important taxonomical character of this holotype.

Head is with short rostrum and subrounded lateral cephalic lobes (fig. 7A). Body is moderately strong, mesosomal segments 1-3 smooth; metasomal segments 1-3 with 4-5 short dorsoposterior marginal setae each. Urosomal segment 1 on each dorsolateral side with one spine and one seta, on urosomal segment 2 appear 2 strong spines on each dorsolateral side); urosomal segment 3 is naked (fig. 7F). Urosomal segment 1 at each ventroposterior margin with 2 single strong spines (fig. 7F) (overlooked by previous researches).

Epimeral plates 1-3 are rather acute, with well defined ventroposterior acute corner defined by one strong spine-like seta, posterior margin is slightly inclined, with setae or single spine-like setae; at ventral margin of epimeral plate 2 appear 2 subventral spines, that of epimeral plate 3 appear 3 strong spines (see Karaman, S. 1956, fig. 5).

Antenna 1 and antenna 2 are described well by S. Karaman (1956). Antenna 1: peduncular articles 1-3 progressively shorter (ratio: 67:50:28), very scarcely setose (fig. 7B); main flagellum with 28 articles (most of them with 2 aesthetascs). Accessory flagellum 2-articulate, not exceeding half of last peduncular article (fig. 7B).

Antenna 2 is moderately slender; peduncular article 3 is short, with distal bunch of setae. Peduncular article 4 is rather longer than article 5 (ratio: 68:60), both articles with several bunches of lateral and distal setae (the longest setae exceeding the diameter of articles themselves); flagellum longer than last 
peduncular article and consisting of 12 relatively slender articles; antennal gland cone reaching distal tip of peduncular article 3 (fig. 7C).

Mouthparts are well developed. Labrum broader than long, entire distally (fig. 9A). Labium with small inner lobes and subrounded outer lobes.

Left mandible: incisor with 5 teeth, lacinia mobilis with 4 teeth accompanied by 6 rakers. right mandible ?. Mandibular palpus article 2 with 14 setae (fig. 7D); article 3 is falciform, longer than article 2 (ratio: 66:48), with nearly $30 \mathrm{D}$-setae and 7 distal E-setae, on outer face appear 5 A-setae, on inner face are attached $6 \mathrm{~B}$-setae $(2+2+2)$.

Maxilla 1: inner plate is with 4 setae of unequal length (fig. 7E); outer plate with 7 spines bearing different number of lateral teeth [inner spine with 5 very short lateral teeth, one spine with 3 stronger lateral teeth, 5 spines with one strong lateral tooth]; palpus 2-articulated, short, not reaching distal tip of outer plate-spines and provided with 7-8 long setae.

Maxilla 2: inner plate is smaller than outer one, with numerous distal and distolateral marginal setae (fig. 9B), outer plate with numerous distal setae only, facial setae are absent.

Maxilliped: Inner plate is short, not reaching outer tip of palpus article 1 and provided with 3 distal spines mixed with several setae (fig. 8A); outer plate reaching nearly half of palpus article 2, and provided with nearly 9 distolateral smooth pointed spines. Palpus article 3 at outer margin with one median and one distal bunch of setae; palpus article 4 at inner margin with 4 setae near basis of the nail (fig. 8A).

Coxae 1-4 are not elongated, provided with several distal setae each. Coxa 1 is short, rhomboid, broader than long (ratio: 49:32), with subrounded ventroanterior margin (fig. 9C); coxae 2-3 are poorly longer than broad, with several longer distal setae; Coxa 4 is slightly longer than broad (ratio: 61:54), ventroposterior lobe is not fully developed and concave (fig. 9E), coxa 5 is only slightly shorter than coxa 4, bilobed. Coxa 6 is shorter than coxa 5 , bilobed; coxa 7 is shallow, entire.

Gnathopods 1-2 are moderately large, with propodus slightly larger than corresponding coxa. Gnathopod 1 is smaller than 2, article 3 at posterior margin with one bunch of setae; article 5 is shorter than propodus, at anterior margin with one distal bunch of setae. Propodus is trapezoid, as long as broad, along posterior margin with 8 transverse rows of setae (fig. 8B); palm inclined distinctly half of propodus length, defined at outer face with one S-spine accompanied laterally by 3 slender L-spines and 3 facial M-setae, at inner margin by one subcorner R-spine (fig. 8C); dactylus along outer margin with row of 5-6 setae, along inner (mesial) margin with row of short setae (fig. 8B).

Gnathopod 2: article 3 is with one bunch of setae at posterior margin; article 5 is shorter than 6; with one bunch of setae at anterior distal margin. Propodus is trapezoid, hardly longer than broad (ratio: 95:90), along posterior margin with 10 transverse rows of setae (fig. 8D). Palm is inclined nearly half of propodus, defined on outer face by one corner S-spine accompanied laterally by 
3 L-spines and facial 2-3 M-setae, on inner face by one subcorner R-spine (fig. $8 \mathrm{E}$ ). Dactylus is with 6 setae at outer margin and several short setae at inner margin (fig. 8D).

Pereopods 3-4 are moderately slender, poorly setose. Pereopod 3 is rather similar to pereopod 4 but hardly longer; dactylus is short, at inner margin with bunch of 2 unequal slender spines near basis of the nail (fig. 9D), at outer margin with one median plumose seta; nail is shorter than pedestal (ratio: 31:42).

Pereopod 4: article 2 at anterior and posterior margin with several proximal long setae (fig. 9E). Articles 4-6 of unequal length (ratio: 45:38:41). Article 4 at anterior margin with 3 bunches of slender spines, at posterior margin with 4 bunches of setae; article 5 at posterior margin with several spines and short setae; article 6 along posterior margin with 5 groups of short spines. Left dactylus is much shorter than article 6 (ratio: 15:41), provided at inner margin with bunch of one stronger and one weak spine near basis of the nail, accompanied by one median slender spine (fig. 9G); right dactylus like left one but without median slender spine at inner margin (fig. 9F), outer margin of both dactyls with one median plumose seta, nail is shorter than pedestal.

Pereopods 5-7 are rather elongated, pereopod 5 is rather shorter than margin with several spines, pereopods 6 and 7. Article 2 of pereopod 5 and pereopod 6 is longer than broad, along anterior along posterior slightly convex margin with row of short setae, ventroposterior lobe is not developed.

Pereopod 7: article 2 is longer than broad (ratio: 91:60), along anterior slightly convex margin are attached 8 groups of short spines, along posterior slightly convex margin appear 13 short setae, ventroposterior lobe is not developed (fig. 8F). Articles 4-6 are of unequal length (ratio: 60:82:110), along both margins with strong spines mixed with single setae. Article 2 is rather shorter than 6 (ratio: 91:110) (fig. 8G). Dactylus is much shorter than article 6 (ratio: 27:110), strong, at inner margin with one spine and seta near basis of the nail, at outer margin with one median plumose seta (fig. $8 \mathrm{H}$ ); nail is shorter than pedestal (ratio: 25:53).

Pleopods are with 3-5 retinacula; peduncle of pleopod 1 with 3 setae at anterior margin (fig. 9H); pleopod 2 is missing (figured by S. Karaman 1956, fig. 6); peduncle of pleopod 3 at posterior margin with 3 setae (fig. 9 I).

Uropod 1 peduncle strong, with dorsoexternal and dorsointernal row of strong spines (fig. 7F); rami of equal length, shorter than peduncle, outer ramus with several lateral and distal short spines and several short simple setae (fig. $7 \mathrm{~F}$ ); inner ramus with several lateral and distal spines and one bunch of 2 simple median setae.

Uropod 2: inner ramus is slightly longer than outer one, both rami with several lateral and distal short spines (fig. 7F).

Uropod 3 is well figured by S. Karaman (1956, fig. 4), relatively short: peduncle is short, with bunch of distal spines; inner ramus is scale-like, as long as broad, with one distal spine and one plumose seta; outer ramus with 2 articles: first article along outer margin with 5 bunches of spines; along inner (mesial) 
margin are attached 7 groups of spines accompanied by single plumose setae. Second article of outer ramus is much shorter than first article (ratio: 27:75), narrowed, but distinctly longer than diameter of first article-tip, provided with several short lateral and distal setae.

Telson is relatively short, slightly longer than broad (ratio: 38:32) [80:73 on slide] incised nearly $2 / 3$ of telson-length, each lobe is tapering distally and provided with 3 distal spines, one spine at outer margin and one facial spine [the longest spines are remarkably shorter than half of telson-length]. A pair of plumose setae is attaches near the external middle of each lobe (fig. 7G).

The female is unknown, but probably similar to males, like other Orniphargus taxa.

The small male $6.0 \mathrm{~mm}$ (juv.) from Thessaly:

Body like that of holotype. Metasomal segments 1-3 with 4 short dorsoposterior setae.

Urosomal segment 1 on each dorsolateral side with 3 strong spines, urosomal segment 2 with 2 strong dorsolateral spines on each side, urosomal segment 3 naked. Urosomal segment 1 at ventroposterior margin with 2 single spines, like that in holotype (fig. 9J). Epimeral plates 1-3 are slightly acute, like these in holotype, epimeral plate 2 with 2 submarginal spines, epimeral plate 3 with 3 submarginal spines.

Antenna 1 reaching half of body-length, main flagellum consisting of 20 articles. Flagellum of antenna 2 is with 7 articles, antennal gland cone reaching distal tip of peduncular article 3.

Mouthparts mainly like that in holotype. Mandibular palpus article 2 with 9 setae, article 3 with 2 A-setae, 4 B-setae, 18 D-setae and 5 E-setae.

Maxilla 1: inner plate with 2 setae, outer plate with 7 spines bearing different number of lateral teeth [3-1-2-1-1-1-1]; palpus short, hardly exceeding basis of outer plate-spines, bearing 4 distal setae.

Maxilliped: inner plate with 3 distal spines, outer plate with nearly 8 distolateral spines; palpus article 4 at inner margin with 2 setae near basis of the nail.

Coxae and gnathopods 1-2 like these in holotype, with palm inclined up to half of propodus-length, $2 \mathrm{~L}$ spines are sitting laterally of S-spine, one subcorner $\mathrm{R}$-spine is sitting on inner face; dactylus is with 3 setae at outer margin.

Dactylus of P3-P7 with one spine at inner margin near basis of the nail. Article 2 of pereopods 5-7 is without distinct ventroposterior lobe.

Pleopods 1-3 with 3 retinacula each. Peduncle of pleopod 1 along anterior margin with 2 median and one distal seta; peduncle of pleopod 2 naked; peduncle of pleopod 3 at posterior margin with 2 medial and one distal seta.

Uropod 1 with equal rami; uropod 2 with inner ramus slightly longer than outer one.

Uropod 3 is rather more stout than that of holotype, along outer margin with 5 bunches of spines, along inner (mesial) margin with 6 groups of spines 
mixed with single plumose setae; inner ramus is short, scale-like, with one distal spine and plumose seta (fig. 9K); second article of outer ramus is rather short, with 4 lateral short simple setae.

Telson is slightly longer than broad (ratio: 70:63), incised over $3 / 4$ of telson-length; each lobe with 3 distal long spines rather shorter than half of telson-length; one spine and one pair of plumose setae are attached near the middle of outer margin; facial spines absent (fig. 9L).

LOCUS TYPICUS: Cave Draconera, Attica (= Attique), Greece.

DISTRIBUTION: Draconera Cave in Attica (S. Karaman 1956); spring along road Lamia--Larissa in Thessaly (present work).

\section{REMARKS.}

As some body-parts of holotype on two slides were preserved not in Faure liquid, but in some other, not soluble liquid, we couldn't move the body parts for better drawing, and we figured them directly from the slides (gnathopods, pereopod 7, telson, maxilla 1, maxilla 2 and maxilliped); but some other parts we figured from holotype preserved in ethanol. Some body parts are very well figured and described by S. Karaman (1956) [telson, uropod 3, propodus of gnathopod 2, epimeral plates, retinacula] and we have not figured all of them again. Propodus of gnathopod 2 is figured here to show the relative size and shape of gnathopods 1 and 2 .

The presence of pair of spines in some of dactylus in pereopods 3-4 seems to be not of taxonomical value but probably only occasional case. These additional spines are not present in the male from Thessaly.

The most visible taxonomic character of this species is presence of 2 ventroposterior single spines on urosomal segment 1 near basis of uropod 1peduncle, overlooked by previous scientists (fig. 7F, 9J). This rare character is not present in other Niphargus taxa known from Greece. We found this character also in Niphargus bodoni G. Karaman, 1983 [loc. typ.: springs of Cassana, La Spezia, Italy] (G. Karaman, 1993) and only several other species of genus Niphargus, but all of them differ remarkably from $N$. lindbergi by combination of numerous other taxonomical characters.

Based on its taxonomical characters, $N$. lindbergi belongs to the subgenus Orniphargus S. Karaman 1950 [typus subgeneris: Niphargus orcinus Joseph 1862], presented in Greece by 2 taxa only: Niphargus lindbergi and N. lourensis Fišer et al. 2006 [loc. typ.: Spring of Louros River, Vouliasta, Ioannina (=Ionannina), Epirus, Greece]. N. lourensis differs remarkably from $N$. lindbergi by presence of 2 retinacula on pleopods $1-3$, by absence of lateral and facial spines on telson, etc.

The subgenus Orniphargus is relatively well defined based on morphological characters mentioned by S. Karaman (1950a, 1950b, G. Karaman 1984) within the genus Niphargus. 
Based on the new investigation on limited molecular-genetic level of members of genus Niphargus, numerous different taxonomical categories with or without established distinct morphological differences are created (Delić et al. 2017, etc.) what made difficult recognition of taxa, and category subspecies is ignored by this way. Only the combined data of all kinds of investigations (not only limited molecular-genetic) will show the real and useful taxonomical categories within present genus Niphargus. Various authors recently argued about these taxonomical problems (Padial et al. 2010, Timm, 2012, etc.), and the further studies will probably put more light on the validation of taxonomical categories.

\section{REFERENCES}

Barnard, J.L \& Barnard, C.M. 1983. Freshwater amphipods of the World. I. Evolutionary patterns. II. Handbook and bibliography-Hayfield Associates: Mt. Vernon, Virginia, 1983, pp. XIX +849 pages, 50 figs., 7 graphs, 98 maps, 12 tables

Delić, T., Švara, V., Coleman, C.O., Trontel, P. \& Fišer, C. 2017. The giant cryptic amphipod species of the subterranean genus Niphargus (Crustacea, Amphipoda).- Zool. Scripta, 00:1-13. https://doi.org/10.1111/zsc.12252.

Fišer, C., Trontelj, P. \& Sket, B. 2006. Phylogenetic analysis of the Niphargus orcinus species-aggregate (Crustacea: Amphipoda: Niphargidae) with description of new taxa.- Journal of Natural History 40 (41-43): 22652315, 23 figs, $1 \mathrm{pl}$.

Karaman G. 1969. XXVII. Beitrag zur Kenntnis der Amphipoden. Arten der Genera Echinogammarus Stebb. und Chaetogammarus Mart. an der jugoslawischer Adriaküste. Glasnik Republičkog zavoda za zaštitu prirode $i$ Prirodnjačke zbirke u Titogradu 2: 59-84, 51 figs.

Karaman, G. 1972. Le probleme du Genre Niphargus en Yougoslavie.- Actes du Ier Colloque International sur le genre Niphargus-Verona, 15-19 Aprile 1969, Museo Civico di Storia Naturale, Verona, Memorie fuori serie, 5: 110.

Karaman, G. 1984. Revision of the Niphargus orcinus-Group, Part. I. (Fam. Niphargidae) (Contribution to the Knowledge of the Amphipoda 130). Glasnik Odjeljenja prirodnih nauka, Crnogorska akademija nauka i umjetnosti, Titograd, 4: 7-79, figs. I-XXXII.

Karaman, G. \& Ruffo, S. 1986. Amphipoda: Niphargus-Group (Niphargidae sensu Bousfield, 1982), in: Botosaneanu, L. (edit.): Stygofauna Mundi, A Faunistic, Distributional, and Ecological Synthesis of the World Fauna inhabiting Subterranean Warers (including the Marine Interstitial), Leiden, E. J. Brill/ Dr. W. Backhuys, pp. 514-534.

Karaman, G. 1993. Crustacea Amphipoda di acqua dolce. - Fauna d'Italia, vol. XXXI: 1-337, Edizione Calderini Bologna, Italia.

Karaman, G. 2012. Further investigations of the subterranean genus Niphargus Schiödte, 1849 (fam. Niphargidae) in Serbia (Contribution to the 
Knowledge of the Amphipoda 264). Agriculture and Forestry, Podgorica, 58 (2): 45-64, 7 figs.

Karaman, G. 2017. Niphargus cymbalus, new species and $N$. jovanovici S. Kar. 1931 in Greece (Contribution to the Knowledge of the Amphipoda 298).Agriculture \& Forestry, Podgorica, 63 (4): 263-279, figs. 1-6.

Karaman, S. 1929. Beiträge zur Kenntnis der Amphipoden Jugoslawiens.Zoologischer Anzeiger, Leipzig, 85 (9/10): 218-225, figs. 1-4.

Karaman, S. 1943. Die unterirdischen Amphipoden Südserbiens.- Srpska Kraljevska Akademija, Posebna izdanja, knj. 135, Prirodnjački i matematički spisi, knj. 34, Ohridski Zbornik, Beograd, 4: 1-312, figs. 1215.

Karaman, S. 1950a. Podrod Orniphargus u Jugoslaviji. I. Deo. (=Das Subgenus Orniphargus in Jugoslavien, Teil I.).- Srpska Akademija Nauka, Posebna Izdanja knj. 158, Odelenje Prirodno-matematičkih nauka, Beograd, 2: 119136, 145-156, 160-167, figs. 1-61.

Karaman, S. 1950b. Podrod Orniphargus u Jugoslaviji. II. Deo. (=Das Subgenus Orniphargus in Jugoslavien, Teil II.).- Srpska Akademija Nauka, Posebna Izdanja knj. 158, Odelenje Prirodno-matematičkih nauka, Beograd, 2: 137-146, 156-159, 168-174, figs. 62-82.

Karaman, S. 1950c. Novi amfipodi podzemne faune Grčke [ Neue Amphipoden der unterirdischen Fauna Griechenlands].- Rad, Jugoslavenska Akademija znanosti i umjetnosti, Zagreb, 280 (Odjel za prirodne i medicinske nauke), 3: 106-114, figs. 1-20 (pp. 43-50, figs. 1-20).

Karaman, S. 1956. III. Beitrag zur Kenntnis griechischer Niphargiden.- Folia Balcanica, Zavod za Ribarstvo na N. R. Makedonija, Skopje, 1 (1): 1-8, figs. 1-9.

Padial, J.M., Miralles, A., De la Riva, I. \& Vences, M. 2010. Review The integrative future of taxonomy.- Frontiers in Zoology 7, 1-16.

Pesce, G.L. \& Maggi, D. $1983 . \quad$ Ricerche faunistiche in acque sotterranee freatiche della Grecia Meridionale ed insulare e stato attuale delle conoscenze sulla stygofauna di Grecia.- Natura, Milano, 74 (1-2): 15-73.

Timm, T. 2012. About the scientifc names of paraphyletic taxa.- Turk. Journal of Zoology, 36 (1): 139-140. TÜBİTAK, doi:10.3906/zoo-1002-52. 